\title{
RESEARCH
}

Open Access

\section{RETRACTED ARTICLE: Ethaselen synergizes with oxaliplatin in tumor growth inhibition by inducing ROS production and inhibiting TrxR1 activity in gastric cancer}

Haiyong Zhang ${ }^{1,2+}$, Jing $\mathrm{Wu}^{1+}$, Jinqiu Yuan ${ }^{3+}$, Huafu $\mathrm{Li}^{1,2}$, Yawei Zhang ${ }^{1,2}$, Wang Wu ${ }^{1,2}$, Wei Chen ${ }^{4}$, Chunming Wang ${ }^{1,2}$, Sijun Meng ${ }^{1}$, Songyao Chen ${ }^{1}$, Mingyu Huo ${ }^{1 *}$, Yulong He ${ }^{1,2^{*}}$ and Changhua Zhang ${ }^{1,2^{*}}$

This article was published in error and has been removed. All authors agree to this retraction.
Received: 4 November 2020 Accepted: 7 February 2021

Published online: 19 August 2021

Author details

'Digestive Diseases Center, The Seventh Affiliated Hospital, Sun Yat-sen University, 518107 Shenzhen, Guangdong, China. ${ }^{2}$ Department of Gastrointestinal Surgery, The First Affiliated Hospital, Sun Yat-sen University, 510080 Guangzhou, Guangdong, China. ${ }^{3}$ Clinical Research Center, The Seventh Affiliated Hospital, Sun Yat-sen University, 518107 Shenzhen, Guangdong, China. ${ }^{4}$ Department of Pathology, The Seventh Affiliated Hospital, Sun Yat-Sen University, 518107 Shenzhen, Guangdong, China.

*Correspondence: mingyu9318@163.com; heyulong@mail.sysu.edu.cn; zhchangh@mail.sysu.edu.cn

${ }^{\dagger}$ Haiyong Zhang, Jing Wu, Jinqiu Yuan contributed equally to this work. 'Digestive Diseases Center, The Seventh Affiliated Hospital, Sun Yat-sen University, 518107 Shenzhen, Guangdong, China

Full list of author information is available at the end of the article

Ready to submit your research? Choose BMC and benefit from:

- fast, convenient online submission

- thorough peer review by experienced researchers in your field

- rapid publication on acceptance

- support for research data, including large and complex data types

- gold Open Access which fosters wider collaboration and increased citations

- maximum visibility for your research: over 100M website views per year

At BMC, research is always in progress.

Learn more biomedcentral.com/submissions

(c) The Author(s). 2021 Open Access This article is licensed under a Creative Commons Attribution 4.0 International License, which permits use, sharing, adaptation, distribution and reproduction in any medium or format, as long as you give appropriate credit to the original author(s) and the source, provide a link to the Creative Commons licence, and indicate if changes were made. The images or other third party material in this article are included in the article's Creative Commons licence, unless indicated otherwise in a credit line to the material. If material is not included in the article's Creative Commons licence and your intended use is not permitted by statutory regulation or exceeds the permitted use, you will need to obtain permission directly from the copyright holder. To view a copy of this licence, visit http://creativecommons.org/licenses/by/4.0/ The Creative Commons Public Domain Dedication waiver (http://creativecommons.org/publicdomain/zero/1.0/) applies to the data made available in this article, unless otherwise stated in a credit line to the data. 